\title{
Effects of green tea on insulin sensitivity, lipid profile and expression of PPAR $\alpha$ and PPAR $\gamma$ and their target genes in obese dogs
}

\author{
Samuel Serisier ${ }^{1,2}$, Veronique Leray ${ }^{2}$, Wilfried Poudroux ${ }^{1,2}$, Thierry $\operatorname{Magot}^{1}$, Khadija Ouguerram $^{1}$ \\ and Patrick Nguyen ${ }^{2} *$ \\ ${ }^{1}$ INSERM U539, University Hospital, Nantes, France \\ ${ }^{2}$ Nutrition and Endocrinology Unit, National Veterinary School of Nantes, France
}

(Received 16 April 2007 - Revised 29 September 2007 - Accepted 3 October 2007 - First published online 6 December 2007)

As in man, canine obesity is associated with insulin resistance, dyslipidaemia and other chronic diseases. This study was designed to examine the effects of a nutritional supplement (green tea) on insulin sensitivity and plasma lipid concentrations in an obese insulin-resistant dog model. We also determined mRNA expression of two transcription factors, PPAR $\gamma$ and PPAR $\alpha$, and some of their target genes, including GLUT4, lipoprotein lipase (LPL) and adiponectin. Obese dogs were divided into two groups: a green tea group $(n 6)$; a control group $(n 4)$. Dogs in the green tea group were given green tea extract $(80 \mathrm{mg} / \mathrm{kg}$ per d) orally, just before their single daily meal, for 12 weeks. Insulin sensitivity (using a euglycaemic-hyperinsulinaemic clamp) and concentrations of plasma TAG, total cholesterol and NEFA were assessed in each group. Gene expression was measured in visceral and subcutaneous adipose tissues and in liver and skeletal muscle, by real-time PCR. At 12 weeks in the green tea group, mean insulin sensitivity index was 60 (SEM 11 ) \% higher $(P<0.05)$ and TAG concentration 50 (SEM 10) \% lower $(P<0.001)$, than baseline. PPAR $\gamma$, GLUT4, LPL and adiponectin expression were significantly higher in both adipose tissues, whilst PPAR $\alpha$ and LPL expression were significantly higher in skeletal muscle, compared with baseline. These findings show that nutritional doses of green tea extract may improve insulin sensitivity and lipid profile and alter the expression of genes involved in glucose and lipid homeostasis.

Obese dogs: Green tea: Catechins: Insulin resistance: Dyslipidaemia: PPAR

There is abundant evidence that, worldwide, obesity and type 2 diabetes have dramatically increased over recent decades ${ }^{(1)}$. Obesity is closely associated with insulin resistance and other chronic conditions, including dyslipidaemia, hypertension and CVD, all components of the metabolic syndrome ${ }^{(2,3)}$. Tea, from Camellia sinensis, exists in three basic forms: fermented black tea; semi-fermented oolong tea; non-fermented green tea ${ }^{(4)}$. Due to inactivation of polyphenol oxidase, green tea is rich (up to $30 \%$ of the dry leaf weight) in flavanols known as catechins ${ }^{(5)}$. Catechins have been reported to have many biological effects, including anti-mutation ${ }^{(6)}$, anti-carcinogenesis $^{(7)}$, anti-oxidation ${ }^{(8)}$ and anti-angiogenesis ${ }^{(9)}$ properties.

Research into the relationship between green tea and obesity-related insulin resistance syndrome has shown that green tea enhances in vitro insulin activity ${ }^{(10)}$, enhances insulin sensitivity in human subjects ${ }^{(11)}$ and rat ${ }^{(12)}$, and reduces hypertriacylglycerolaemia in mice ${ }^{(13)}$. The main active component in green tea mediating these effects seems to be epigallocatechin gallate $(\mathrm{EGCG})^{(14,15)}$.

Mechanisms explaining the effects of green tea and its components on obesity-related metabolic disturbances are not fully understood and some findings are contradictory. For example, one study reported that green tea decreased the translocation of the insulin-dependent GLUT4 in adipose tissue ${ }^{(16)}$ while another $^{(17)}$ found an increasing effect of green tea on GLUT4 content of adipocytes. There are also conflicting findings on the relationship between green tea polyphenols and the important transcription factors involved in lipid and glucose homeostasis $\left(\operatorname{PPAR} \alpha^{(18,19)}\right.$ and PPAR $\left.\gamma^{(16,20)}\right)$. Furthermore, many studies used high concentrations of catechins that may not reflect typical consumption.

Our laboratory has demonstrated that obesity in the dog produces a metabolic disorder nearly identical to that seen in the obese human subject ${ }^{(21,22)}$. Moreover, the dog genome has been sequenced ${ }^{(23)}$ supporting use of the obese dog as a model to study human metabolic disorders and link these changes to molecular studies.

The purpose of the present study in dogs was to examine the effects of extended nutritional supplementation with green tea on insulin sensitivity and plasma lipid concentrations and to determine whether transcriptional changes occur in liver, skeletal muscle and/or visceral and subcutaneous adipose tissue. We measured the expression of PPAR $\alpha$ and PPAR $\gamma$ in their specific tissues and the expression of target genes including lipoprotein lipase (LPL), adiponectin and GLUT4; LPL expression is mediated by both PPAR $\alpha$ and PPAR $\gamma$ whereas adiponectin and GLUT4 expression is mediated only by $\operatorname{PPAR} \gamma^{24}$. 


\section{Materials and methods}

Animals and diet

The ten obese and insulin-resistant beagle dogs (neutered females) were all healthy adults (mean age 4 years) with a mean body weight of 14.2 (SEM 0.4 ) kg (ideal body weight $10 \cdot 1($ SEM $0 \cdot 2) \mathrm{kg}$ ). All had a body condition score of 7 or 8 on the 9-point scale ${ }^{(25)}$. They were housed at the National Veterinary School of Nantes according to the regulations for animal welfare of the French Ministry of Agriculture and Fisheries. The experimental protocol adhered to European Union guidelines and was approved by the local Animal Use and Care Advisory Committee.

Before the study for a period of 6 months, the dogs were fed a single hyperenergetic meal each day comprising $28 \mathrm{~g} / \mathrm{kg}$ of a dry commercially available and nutritionally complete diet (18 MJ metabolisable energy $/ \mathrm{kg}, 32 \%$ protein, $20 \%$ fat) to induce obesity. The dogs continued to receive these rations throughout the 12-week study.

Obese and insulin-resistant dogs were randomly divided into two groups: a green tea group ( $n$ 6), a control group $(n 4)$. For 12 weeks, the green tea group received a capsule of green tea extract $(80 \mathrm{mg} / \mathrm{kg}$ per d: a nutritionally relevant, non-pharmacological dose) orally just before the daily meal, whilst the control group received an empty capsule. The freeze-dried green tea extract (Vitamin Shoppe, North Bergen, NJ, USA) contained: epicatechin $35.7 \mathrm{mg} / \mathrm{g}$; epicatechin gallate $64.8 \mathrm{mg} / \mathrm{g}$; epigallocatechin $20.2 \mathrm{mg} / \mathrm{g}$; EGCG $153.1 \mathrm{mg} / \mathrm{g}$. Body weight and food intake were monitored twice weekly.

\section{Body composition}

Body composition was determined using isotopic dilution before and after 12 weeks' supplementation. $\mathrm{D}_{2} \mathrm{O}(99.9 \%$ D/H; Euriso-top, Gif-sur-Yvette, France) was injected subcutaneously following a $24 \mathrm{~h}$ fast, with jugular vein blood samples (into heparin) collected $5 \mathrm{~h}$ later. The whole blood was centrifuged $\left(4^{\circ} \mathrm{C}, 2124 \mathrm{~g}\right.$ for $\left.10 \mathrm{~min}\right)$ and plasma deuterium concentration assessed (using Fourier transform IR spectroscopy; Brüker SA, Wissembourg, France).

\section{Lipid profile}

Jugular vein blood samples were collected once weekly (into EDTA) following a $24 \mathrm{~h}$ fast, for measurement of plasma TAG, total cholesterol (TC) and NEFA concentrations. Blood was immediately centrifuged (at $4^{\circ} \mathrm{C}, 2124 \mathrm{~g}$ for $10 \mathrm{~min}$ ) and stored (at $-80^{\circ} \mathrm{C}$ ) until further analysis.

Fast protein liquid chromatography analysis for lipoprotein separation was performed at room temperature using two P-500 pumps (1 Mpa), a MV-7 place multi-injection with a $200 \mu \mathrm{l}$ loop, two Superose 6HR 10/30 columns in quick succession, a UV monitor UV-1, a FRAC-100 fraction collector and a LCC-501 Plus controller. The absorbance of the eluent was monitored continuously at $280 \mathrm{~nm}$ using a UV monitor. The system was controlled by FPLC DIRECTOR software (Amersham Pharmacia Biotech Inc., Orsay, France). Elution was performed in a $1 \mathrm{~mm}$-EDTA, $154 \mathrm{~mm}-\mathrm{NaCl}$ and $0.02 \% \mathrm{NaN}_{3}(\mathrm{pH} 8.2)$ buffer. The buffer was filtered through a $0.22 \mu \mathrm{m}$ filter (Membrane filters type GV; Duropore ${ }^{\circledR}$,
Millipore). The column was washed with an aqueous ethanol solution $(20 \%)$. Plasma $(200 \mu \mathrm{l})$ was injected and elution was performed at a flow of $0.35 \mathrm{ml} / \mathrm{min}$. The fractions were collected from 35 to $110 \mathrm{~min}$ and the columns were washed for $40 \mathrm{~min}$ at the end of each run. Fast protein liquid chromatography was programmed to collect elution volume from $10 \mathrm{ml}$ to $40 \mathrm{ml}$, which represented seventy-five fractions of $350 \mu \mathrm{l}$ and resolved three lipoprotein fractions: VLDL (fractions 3 to 11 , elution volume 12.95 to $15.75 \mathrm{ml}$ ), to LDL (fractions 15 to 39 , elution volume 17.15 to $25.55 \mathrm{ml}$ ), to HDL1 (fractions 40 to 61 , elution volume 26.90 to $33.25 \mathrm{ml}$ ). These fractions were subsequently analysed for TAG and TC as described later.

\section{Euglycaemic-hyperinsulinaemic clamp}

In vivo insulin sensitivity was determined using a $3 \mathrm{~h}$ euglycaemic-hyperinsulinaemic clamp, performed following a $24 \mathrm{~h}$ fast both before and after 12 weeks' supplementation, as previously described ${ }^{(21)}$. Briefly, hyperinsulinaemia was induced by infusing human insulin (Actrapid; Novo Nordisk, Bagsvaerd, Denmark) via a catheter placed into the cephalic vein $(4 \mathrm{mU} / \mathrm{kg}$ for $1 \mathrm{~min}$ and $2 \mathrm{mU} / \mathrm{kg}$ per min for the duration of the experiment). Glucose (Glucose 20\%; Laboratoire Aguettant, Lyon, France) was clamped at basal level by adjustment of the glucose infusion rate in the cephalic vein. Blood samples were drawn from a jugular catheter every $5 \mathrm{~min}$ from 0 to $60 \mathrm{~min}$ and every $10 \mathrm{~min}$ from 60 to $180 \mathrm{~min}$. These samples were placed in ice-cold heparinized tubes and centrifuged (at $4^{\circ} \mathrm{C}, 2124 \mathrm{~g}$ for $10 \mathrm{~min}$ ) and stored (at $-80^{\circ} \mathrm{C}$ ) until insulin analysis. Insulin sensitivity index was defined as the mean glucose infusion rate $(\mathrm{mg} / \mathrm{kg}$ per min) divided by the mean plasma insulin $(\mu \mathrm{U} / \mathrm{ml})$ of the last 60 min of the clamp ${ }^{(26)}$.

\section{Homeostasis model assessment of insulin resistance index}

Homeostasis model assessment of insulin resistance (HOMAIR) yields a formula for insulin resistance and derives from fasting insulin $\left(\mathrm{I}_{0}(\mathrm{mIU} / \mathrm{l})\right)$ and glucose $\left(\mathrm{G}_{0}(\mathrm{mmol} / \mathrm{l})\right)$ concentrations. This index is defined by:

$$
\text { HOMA-IR }=\mathrm{G}_{0} \times \mathrm{I}_{0} / 22.5 .
$$

\section{Chemical analysis}

Rapid determination of blood glucose during clamping was achieved using the glucose oxidase method (Glucotrend ${ }^{\circledR}$ Plus; Roche Diagnostics, Mannheim, Germany). Plasma insulin concentrations were measured using a commercial RIA kit (RIA Insik-5; Diasorin, Saluggia, Italy). TAG, TC and NEFA were analysed in plasma using enzymatic methods (Triglycérides enzymatiques PAP 150; BioMérieux, Marcy-l'Etoile, France, Cholesterol RTU; Biomérieux, Marcy-l'Etoile, France and NEFA C; WAKO, Oxoid, Dardilly, France).

\section{RNA extraction}

Visceral and subcutaneous adipose tissue and skeletal muscle and liver biopsies were obtained intraoperatively under anaesthesia, following a $24 \mathrm{~h}$ fast both before and after 12 weeks' 
supplementation. Skeletal muscle biopsies were removed from the tibialis anterior. Approximately $100 \mathrm{mg}$ each tissue was cleaned in saline. TRIzol reagent $(1 \mathrm{ml}$; Gibco BRL, Grand Island, NY, USA) was added and the tissue immediately frozen in liquid N. RNA was extracted from frozen tissues using TRIzol reagent according to the manufacturer's instructions. Total RNA concentration was quantified by spectrophotometric absorbance at $260 \mathrm{~nm}$.

\section{Reverse transcription and real-time PCR analysis}

Total RNA $(1 \mu \mathrm{g})$ was reverse-transcribed in a $20 \mu$ l reaction volume using random primers (Pharmacia, Saclay, Orsay Cedex, France) and Superscript II Moloney leukaemia virus RT (according to the manufacture's instructions; Life Technologies, Cergy Pontoise, France).

Quantitative real-time PCR was conducted with a rotorgene 2000 (Ozyme, Saint-Quentin en Yvelines, France) in a $20 \mu \mathrm{l}$ mixture containing 1X SYBR Green (Roche Diagnostic, Meylan, France), 0.25 mM-dNTP, each primer ( $0.5 \mathrm{~mm}), 2 \mathrm{U}$ Taq Titanium DNA polymerase (Ozyme) and $2 \mu \mathrm{l}$ cDNA mixture of each sample. Glyceraldehyde-3-phosphate dehydrogenase was used as a reference for initial RNA loading. The sense/antisense primers (Genosys, Pampisford, UK) were designed using GeneJokey Software (Biosoft, Ferguson, MO, USA). The specificity of PCR primers and the annealing temperature were tested under normal PCR conditions with temperature gradient $\left(55^{\circ} \mathrm{C}\right.$ to $\left.70^{\circ} \mathrm{C}\right)$ as annealing (Table 1).The real-time PCR conditions were $95^{\circ} \mathrm{C}$ for $300 \mathrm{~s}$ (to activate the hot start enzyme) followed by: (1) thirty-five cycles of $95^{\circ} \mathrm{C}$ for $5 \mathrm{~s}, 63^{\circ} \mathrm{C}$ for $10 \mathrm{~s}, 72^{\circ} \mathrm{C}$ for $10 \mathrm{~s}$ and $83^{\circ} \mathrm{C}$ for $15 \mathrm{~s}$ for PPAR $\gamma$; (2) thirty-five cycles of $95^{\circ} \mathrm{C}$ for $5 \mathrm{~s}, 62^{\circ} \mathrm{C}$ for $15 \mathrm{~s}, 72^{\circ} \mathrm{C}$ for $15 \mathrm{~s}$ and $82^{\circ} \mathrm{C}$ for $15 \mathrm{~s}$ for PPAR $\alpha$; (3) forty cycles of $95^{\circ} \mathrm{C}$ for $5 \mathrm{~s}, 62^{\circ} \mathrm{C}$ for $15 \mathrm{~s}, 72^{\circ} \mathrm{C}$ for $15 \mathrm{~s}$ and $86^{\circ} \mathrm{C}$ for $15 \mathrm{~s}$ for the LPL; (4) forty-five cycles of $95^{\circ} \mathrm{C}$ for $5 \mathrm{~s}, 70^{\circ} \mathrm{C}$ for $15 \mathrm{~s}, 72^{\circ} \mathrm{C}$ for $15 \mathrm{~s}$ and $85^{\circ} \mathrm{C}$ for $15 \mathrm{~s}$ for GLUT4; (5) forty cycles of $95^{\circ} \mathrm{C}$ for $5 \mathrm{~s}, 69^{\circ} \mathrm{C}$ for $15 \mathrm{~s}, 72^{\circ} \mathrm{C}$ for $15 \mathrm{~s}$ and $86^{\circ} \mathrm{C}$ for $15 \mathrm{~s}$ for adiponectin; (6) thirty cycles of $95^{\circ} \mathrm{C}$ for $5 \mathrm{~s}, 69^{\circ} \mathrm{C}$ for $15 \mathrm{~s}, 72^{\circ} \mathrm{C}$ for $15 \mathrm{~s}$ and $86^{\circ} \mathrm{C}$ for $15 \mathrm{~s}$ for the glyceraldehyde-3-phosphate dehydrogenase. The fluorescence cycle threshold $(\mathrm{Ct})$ was calculated to quantify the relative amount

Table 1. Sense/antisense primers used for glyceraldehyde-3-phosphate deshydrogenase (GAPDH), PPAR $\alpha$, PPAR $\gamma$, adiponectin, lipoprotein lipase (LPL) and GLUT4 relative quantification and annealing temperatures determined for each PCR primer*

\begin{tabular}{|c|c|c|}
\hline Gene & Primers sense/antisense & Annealing $\mathrm{T}^{\circ} \mathrm{C}$ \\
\hline GAPDH & $\begin{array}{l}5^{\prime} \text {-ACAGTCAAGGCTGAGAACGG-3' } \\
5^{\prime} \text {-CCACAACATACTCAGCACCAGC-3' }\end{array}$ & $69^{\circ} \mathrm{C}$ \\
\hline $\operatorname{PPAR} \alpha$ & $\begin{array}{l}\text { 5'-TTATCACAGACACGCTCTCACC-3' } \\
5^{\prime} \text {-GTGGACTCCGTAATGGTAGC-3' }\end{array}$ & $62^{\circ} \mathrm{C}$ \\
\hline PPAR $\gamma$ & $\begin{array}{l}\text { 5'-CATTTACACGATGCTGGCGTCC-3' } \\
5^{\prime} \text {-CTCCACTGAGAATAATGACGGC-3' }\end{array}$ & $63^{\circ} \mathrm{C}$ \\
\hline Adiponectin & $\begin{array}{l}\text { 5'-CCAGGTCTTGTTGGTCCTAAGG-3' } \\
\text { 5'-ACACTGAATGCCGAACGG-3' }\end{array}$ & $69^{\circ} \mathrm{C}$ \\
\hline LPL & $\begin{array}{l}\text { 5'- GAAGAAAATCCAAGTAAGGC-3' } \\
\text { 5'-ACATTTTGCTCGGTCTTTTGGC-3' }\end{array}$ & $62^{\circ} \mathrm{C}$ \\
\hline GLUT4 & $\begin{array}{l}\text { 5'-GACAAGCAACTTCATCATTGGC-3' } \\
5^{\prime} \text {-AGGAAGGTGAAGATGAAGAAGG-3' }\end{array}$ & $70^{\circ} \mathrm{C}$ \\
\hline
\end{tabular}

${ }^{*}$ For details of procedures, see Materials and methods. of gene expression. Results are expressed according to the $2^{-\Delta \Delta \mathrm{Ct}}$ method $^{(27)}$. The level of expression before green tea supplementation was arbitrarily set at $100 \%$.

\section{Statistical analysis}

Data are expressed as means with their standard errors of the mean. The statistical analysis used Stat View 5.0 software (SAS Institute, Cary, NC, USA). Comparison among means was performed by Student's $t$ test for paired values. A $P$ value $<0.05$ was considered to be significant.

\section{Results}

\section{Body weight, food intake and body composition}

There was no significant difference from baseline in either group in terms of body weight or food intake at any time point. The mean values of the food intake during the 12 weeks of treatment was 578 (SEM 29) $\mathrm{kJ} / \mathrm{kg}^{0.75}$ in the green tea group and 578 (SEM 25) kJ/kg ${ }^{0.75}$ in the control group. At 12 weeks (after treatment), there was no difference from baseline (week 0 , before treatment) in body fat mass in either group (Table 2).

\section{Insulin sensitivity}

The euglycaemic-hyperinsulinaemic clamp data (fasting glucose and insulin, plateau of insulin level, glucose infusion rate and insulin sensitivity index) in normal-weight and obese dogs before and after treatment in the green tea group and in the control group are shown in Table 3 .

Basal glycaemia did not significantly change when dogs became obese in either group (green tea and control). Also, basal glycaemia did not significantly change after treatment compared with baseline (before treatment) in either group. Basal insulinaemia tended to increase when dogs became obese and to decrease after green tea treatment but these changes were not significant. During the clamps, plateau of insulin level increased when the dogs became obese in both groups and tended to decrease after green tea treatment. Glucose infusion rate needed to maintain euglycaemia under hyperinsulinaemic conditions was lower in obese dogs than in normal dogs $(P<0.001)$ in either group and was elevated after green tea treatment $(P<0 \cdot 05)$. Consequently, insulin sensitivity index was markedly decreased when dogs became obese $(-59$ (SEM 12) \% in the green tea group and -73 (SEM 15) \% in the control group compared with normal weight state, $P<0.001$ ). Insulin sensitivity index was markedly increased by green tea supplementation (by 60 (SEM 11)\% compared with baseline (before treatment; $P<0.01$ ), whereas no change was observed in the control group.

HOMA-IR index tended to increase when the dogs became obese $(3.58$ (SEM 0.73) v. 4.68 (SEM 0.76$)$ in the green tea group and 3.35 (SEM 0.81) v. 4.14 (SEM 1.03) in the control group) and to decrease after green tea treatment (4.68 (SEM 0.76) $v$. 3.75 (SEM 0.55)). However these changes are not significant.

\section{Plasma lipid concentration}

Lipid parameter data are summarized in Table 4. 
Table 2. Body weight and body composition of the 12 weeks' green tea-supplemented and control obese dogs*

(Values are presented as means with their standard errors)

\begin{tabular}{|c|c|c|c|c|c|c|c|c|}
\hline & \multicolumn{4}{|c|}{ Green tea $(n 4)$} & \multicolumn{4}{|c|}{ Control $(n 6)$} \\
\hline & \multicolumn{2}{|c|}{ Week 0} & \multicolumn{2}{|c|}{ Week 12} & \multicolumn{2}{|c|}{ Week 0} & \multicolumn{2}{|c|}{ Week 12} \\
\hline & Mean & SEM & Mean & SEM & Mean & SEM & Mean & SEM \\
\hline Body weight (kg) & $13 \cdot 62$ & 0.55 & $13 \cdot 86$ & 0.67 & 14.91 & 0.52 & $15 \cdot 05$ & 0.68 \\
\hline Body fat mass $(\mathrm{kg})$ & $5 \cdot 80$ & 0.48 & $5 \cdot 20$ & 0.61 & 6.01 & 0.40 & $5 \cdot 76$ & 0.28 \\
\hline
\end{tabular}

Diet-induced obesity increased plasma TAG and NEFA by respectively 71 (SEM 19$) \%(P<0.001)$ and 44 (SEM 10) \% $(P<0.05)$ in the green tea group and by 95 (SEM 23$) \%$ $(P<0.05)$ and $43($ SEM 15$) \%(P<0.05)$ in the control group. TC concentrations did not change when dogs became obese in either group.

Plasma TAG ( 48 (SEM 8) \% compared with baseline (before treatment; $P<0.01$ ) and VLDL-TAG were reduced by green tea supplementation, whereas no change was observed in the control group. There was no significant difference from baseline (before treatment) in plasma NEFA, TC, LDL-cholesterol and HDL-cholesterol concentrations in either group. However, plasma NEFA tended to decrease after green tea treatment, whereas plasma NEFA tended to increase in the control group.

mRNA expression of PPAR $\gamma$, lipoprotein lipase, adiponectin and GLUT4 in visceral and subcutaneous adipose tissue

The expression of the reference gene did not significantly change in visceral and subcutaneous adipose tissue between the beginning (week 0) and the end (week 12) of the treatment (data not shown).

Compared with baseline, expression of PPAR $\gamma$, LPL, adiponectin and GLUT4 mRNA in visceral adipose tissue $(n 6)$ was dramatically elevated after 12 weeks of green tea supplementation. Expression was approximately 2-fold greater for PPAR $\gamma(P<0.05)$ and LPL $(P<0.05)$ and 4 -fold greater for adiponectin $(P<0.05)$ and GLUT4 $(P<0 \cdot 05)$, whereas no change was seen in the expression of any of these genes in the control group $(n 4)$ (Fig. 1). Interestingly, in the subcutaneous adipose tissue of green tea-supplemented dogs (n 6), PPAR $\gamma$, LPL, adiponectin and GLUT4 mRNA expression was increased by a similarly great extent (3-fold, 10-fold, 6-fold and 3-fold, respectively, $P<0 \cdot 05$; Fig. 2) compared with baseline.

\section{mRNA expression of PPAR $\alpha$ and lipoprotein lipase in liver}

The expression of the reference gene did not significantly change in liver between the beginning (week 0) and the end (week 12) of the treatment (data not shown).

In liver, the mRNA expression of PPAR $\alpha$, and its target gene, LPL, remained unchanged in both groups (Fig. 3).
mRNA expression of PPAR $\alpha$, lipoprotein lipase and GLUT4 in skeletal muscle

The expression of the reference gene did not significantly change in skeletal muscle tissue between the beginning (week 0) and the end (week 12) of the treatment (data not shown).

In skeletal muscle, green tea supplementation markedly increased the expression of PPAR $\alpha$ (by 100 (SEM 18)\%, $P<0.01$ ) and LPL (by 270 (SEM 43) \%,P<0.01), but not GLUT4, compared with baseline (Fig. 4).

\section{Discussion}

In the present study, we have shown that 12 weeks' green tea supplementation in obese insulin-resistant dogs increases insulin sensitivity, decreases plasma TAG concentrations and increases expression of PPAR $\alpha, \operatorname{PPAR} \gamma$ and their target genes LPL, GLUT4 and adiponectin. Body weight and fat mass were not affected.

Many previous human studies used high concentrations of catechins ${ }^{(20,28)}$ that may not reflect typical consumption. A $2.5 \%(\mathrm{w} / \mathrm{v})$ tea concentration in $227 \mathrm{ml}$ water represents the typical strength of brews consumed by human individuals and may contain approximately $340 \mathrm{mg}$ catechins ${ }^{(29)}$. Thus, based on metabolic body weight $\left(\mathrm{BW}^{0.75}\right)$, the consumption of green tea catechins by the dogs in the current study was nutritionally relevant and non-pharmacological, being equivalent to three cups of tea in human individuals. Dogs readily absorb EGCG (approximately $20 \%$ of the dose) after oral administration $^{(30)}$; it is then distributed widely to a variety of epithelial tissues.

Very few studies have been reported regarding the in vivo effects of green tea or its catechins on insulin sensitivity ${ }^{(1,20,31)}$. Moreover, these studies used glucose tolerance tests rather than the gold standard for assessing insulin sensitivity ${ }^{(32)}$. In the present study, euglycaemic hyperinsulinaemic clamps showed a strong effect of green tea extract in improving insulin sensitivity in obese, insulin-resistant dogs. Fasting insulin concentrations have tended to increase when the dogs became obese and to decrease after green tea treatment. However, basal insulin and glucose concentrations did not significantly change. We have compared our clamp results with the data of HOMA-IR index, a simpler method to measure insulin sensitivity usually used in clinical 
and epidemiological studies when only fasting insulin and glucose values are available. We have found that HOMAIR index tended to increase when the dogs became obese and to decrease after green tea treatment. The changes did not reach the statistical significance level probably due to the small sample size.

To understand the mechanisms that could explain these effects of green tea on insulin sensitivity, we examined the expression of proteins involved in glucose metabolism in visceral and subcutaneous adipose tissue and skeletal muscle. We showed that GLUT4 was markedly increased in visceral and subcutaneous adipose tissues, but not in skeletal muscle, after 12 weeks of green tea supplementation. The insulindependent GLUT4, located in muscle cells and adipocytes, increases the utilization of glucose by these tissues ${ }^{(33)}$. Abel and colleagues presented convincing evidence that insulin resistance was initiated in adipose tissue and that adipose tissue may play a pivotal role in the induction of insulin resistance in muscle and liver ${ }^{(34)}$. This would explain why, in the present study, green tea increased GLUT4 expression in adipose tissue but not in skeletal muscle. We have not examined the translocation of GLUT4 from intracellular storage sites to the plasma membrane. Thus, it is possible that green tea increases GLUT4 translocation and not GLUT4 expression in muscle cells.

The current results also showed that green tea increases adiponectin expression in both types of adipose tissue. Adiponectin is strongly inversely correlated to insulin resistance and improves insulin sensitivity by repressing gluconeogenesis and favouring glucose and NEFA oxidation by muscle ${ }^{(35)}$.

Other mechanisms could explain the effects of green tea catechins on obesity-related insulin resistance. EGCG increases tyrosine phosphorylation of the insulin receptor and insulin receptor substrate $1^{(15)}$. It has also been suggested that tea catechins could lower glucose absorption in the intestinal tract by inhibiting its specific transporters ${ }^{(36)}$.

There have been several epidemiological and clinical investigations of the effects of green tea on plasma lipids in human subjects $^{(31,37,38)}$, with contradictory findings. In rodents, Sayama and co-workers ${ }^{(13)}$ found a TAG-lowering effect of green tea and no change in plasma TC concentrations, whereas Ashida and colleagues ${ }^{(16)}$ reported that green tea supplementation decreased TC, LDL-cholesterol, HDL-cholesterol and NEFA levels with no change in TAG concentrations. The present study found a marked decrease in plasma TAG concentrations in the green tea group related to a decrease in VLDL-TAG. However, no difference was observed in the cholesterol profile or NEFA levels.

LPL is an enzyme that hydrolyses circulating TAG-rich lipoproteins ${ }^{(39)}$. To explain the hypertriacylglycerolaemic effect of green tea, we measured LPL mRNA expression. Our results showed for the first time that LPL expression was dramatically elevated in visceral and subcutaneous adipose tissues, and in skeletal muscle, by green tea supplementation. It has been shown that EGCG is a potent inhibitor of apoB100 secretion ${ }^{(40)}$, possibly through microsomal transfer protein inhibition, as demonstrated in vitro for other flavonoids $^{(41)}$. Furthermore, EGCG promotes the accumulation of TAG in cytosolic lipid droplets, thereby diverting lipids from the assembly of VLDL to storage in the cytosol ${ }^{(42)}$. In vivo measurement of the processes involved in VLDL 
Table 4. Fasting plasma TAG, total cholesterol (TC), NEFA, VLDL-TAG, LDL-cholesterol (LDL-C) and HDL-cholesterol (HDL-C) in green tea group and control group at the normal weight state and at the obese state before and after treatmentł

(Values are presented as means with their standard errors)

\begin{tabular}{|c|c|c|c|c|c|c|c|c|c|c|c|c|}
\hline & \multicolumn{6}{|c|}{ Green tea group $(n 6)$} & \multicolumn{6}{|c|}{ Control group (n 4) } \\
\hline & \multicolumn{2}{|c|}{ Normal weight } & \multicolumn{2}{|c|}{ Before treatment } & \multicolumn{2}{|c|}{ After treatment } & \multicolumn{2}{|c|}{ Normal weight } & \multicolumn{2}{|c|}{$\begin{array}{l}\text { Before } \\
\text { treatment }\end{array}$} & \multicolumn{2}{|c|}{ After treatment } \\
\hline & Mean & SEM & Mean & SEM & Mean & SEM & Mean & SEM & Mean & SEM & Mean & SEM \\
\hline TAG (mmol/l) & 0.69 & 0.05 & 1.16†十† & 0.10 & $0.58^{\star \star}$ & 0.06 & 0.55 & 0.02 & $1.05 \dagger$ & 0.10 & $0.98 \dagger$ & 0.17 \\
\hline $\mathrm{TC}(\mathrm{mmol} / \mathrm{l})$ & $6 \cdot 35$ & 0.42 & $6 \cdot 24$ & 0.48 & $6 \cdot 85$ & $0 \cdot 21$ & 6.07 & 0.76 & $6 \cdot 97$ & $1 \cdot 12$ & 6.79 & 0.63 \\
\hline VLDL-TG (mmol/l) & \multicolumn{2}{|c|}{ NA } & 0.537 & 0.093 & $0.273^{\star *}$ & 0.042 & \multicolumn{2}{|c|}{ NA } & 0.385 & 0.032 & 0.453 & 0.067 \\
\hline LDL-C (mmol/l) & \multicolumn{2}{|c|}{ NA } & 0.881 & 0.169 & 0.999 & 0.173 & \multicolumn{2}{|c|}{ NA } & $1 \cdot 016$ & 0.243 & 0.916 & 0.142 \\
\hline HDL-C (mmol/l) & \multicolumn{2}{|c|}{ NA } & $5 \cdot 374$ & 0.403 & 5.448 & 0.388 & \multicolumn{2}{|c|}{ NA } & $5 \cdot 377$ & 0.860 & $5 \cdot 381$ & 0.753 \\
\hline
\end{tabular}

NA, not available.

${ }^{\star \star} P<0.01 \mathrm{v}$. before treatment.

$\dagger P<0.05 ; \dagger \dagger+P<0.001 \mathrm{v}$. normal weight state

$\mp$ For details of animals and procedures, see Materials and methods.

metabolism, particularly apoB100 and LPL activity, would be required to explain the hypotriacylglycerolaemic effects of green tea.

PPAR are transcription factors for the genes involved in glucose and lipid homeostasis, including LPL, adiponectin and GLUT4. Three isotypes of PPAR have been identified $(\alpha, \gamma, \beta / \delta)$. The amino acid sequence of the ligand binding domain of PPAR $\alpha$ in the dog was found to be $97 \%$ identical to that of man. PPAR $\alpha$ is predominantly expressed in tissues with a high rate of fat catabolism (e.g. liver and muscle). The expression of PPAR $\gamma$ is high in adipose tissue, where it triggers adipocyte differentiation and induces the expression of genes critical for adipogenesis (for review see ${ }^{(24)}$ ). We have shown that green tea increases

(a)

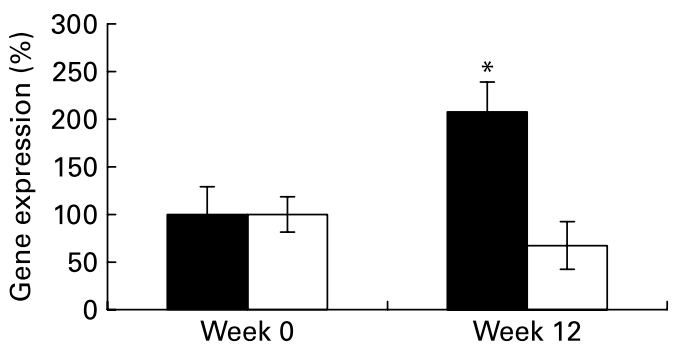

(c)

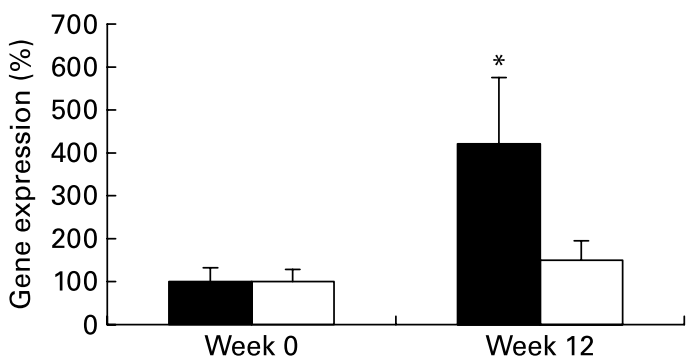

PPAR $\alpha$ expression in skeletal muscle (but not in liver) and increases PPAR $\gamma$ expression in visceral and subcutaneous adipose tissues.

Tea catechins activated PPAR $\alpha$ in cell culture ${ }^{(19)}$ and increased PPAR $\alpha$ and PPAR $\gamma$ expression in hamster liver ${ }^{(20)}$. The use of fenofibrate ${ }^{(43)}$ and other PPAR $\alpha$ activators $^{(44)}$ showed that the induction of PPAR $\alpha$ mRNA might be a property shared by all members of this class of chemical. Moreover, Davies et al. ${ }^{(45)}$ showed that the ability of troglitazone, a thiazolidinedione, to up regulate PPAR $\gamma$ could be due to its antioxidant properties. Green tea catechins are potent antioxidants ${ }^{(8)}$ and, thus, could act similarly. Antioxidants (via intracellular redox state) could regulate the transcription factors, NF- $\mathrm{BB}$ and activator protein- ${ }^{(46)}$, and PPAR $\gamma$ could (b)

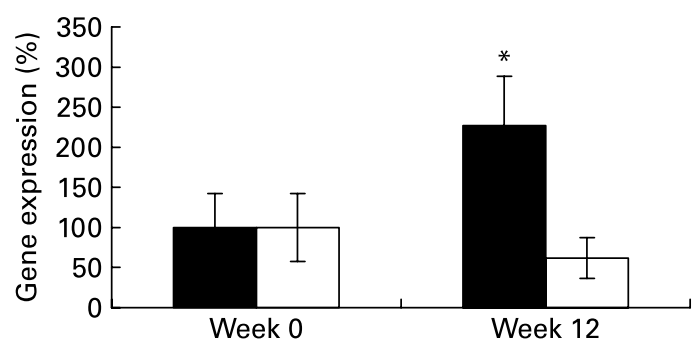

(d)

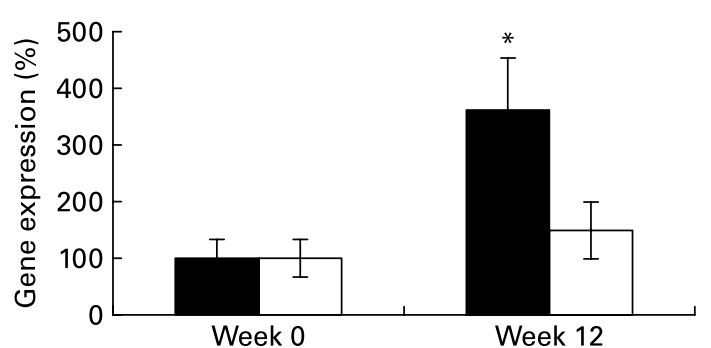

Fig. 1. Relative expression of (a) PPAR $\gamma$, (b) lipoprotein lipase (LPL), (c) adiponectin and (d) GLUT4 mRNA in visceral adipose tissue of 12 weeks' green teasupplemented $(\mathbf{\square} ; n 6)$ and control $(\square ; n 4)$ obese dogs. Values are presented as means with their standard errors. ${ }^{\star} P<0.05 v$. baseline (week 0$)$. For details of animals and procedures, see Materials and methods. 
(a)

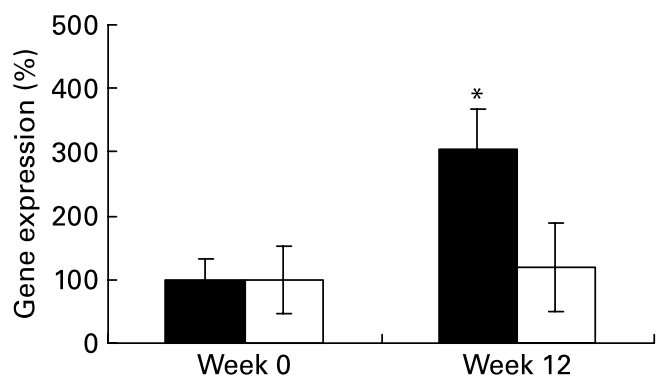

(c)

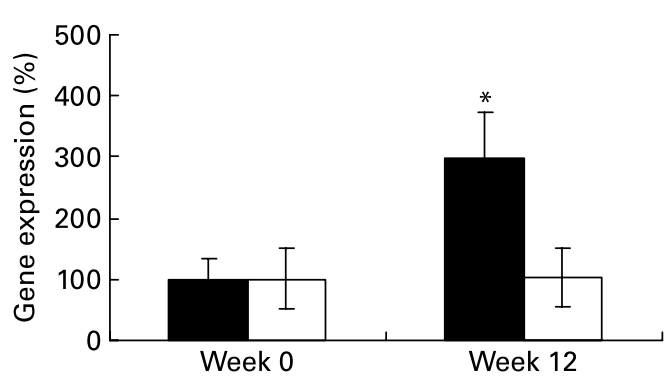

(b)

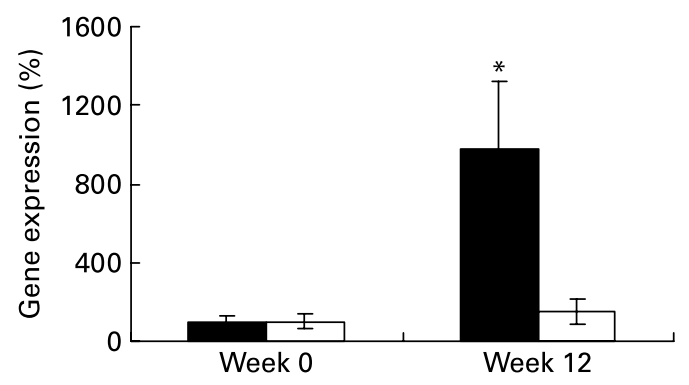

(d)

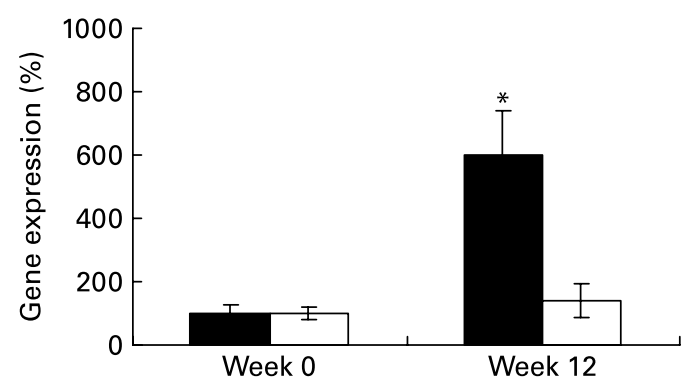

Fig. 2. Relative expression of (a) PPAR $\gamma$, (b) lipoprotein lipase (LPL), (c) GLUT4 and (d) adiponectin mRNA in subcutaneous adipose tissue of 12 weeks' green tea-supplemented $(\square ; n 6)$ and control $(\square ; n 4)$ obese dogs. Values are presented as means with their standard errors. ${ }^{*} P<0.05 v$. baseline (week 0$)$. For details of animals and procedures, see Materials and methods.

be regulated by these transcription factors ${ }^{(47)}$. Given the increase in the expression of PPAR $\alpha$ and PPAR $\gamma$ and their target genes in their specific tissues, we hypothesize that tea catechins might represent new PPAR activators.
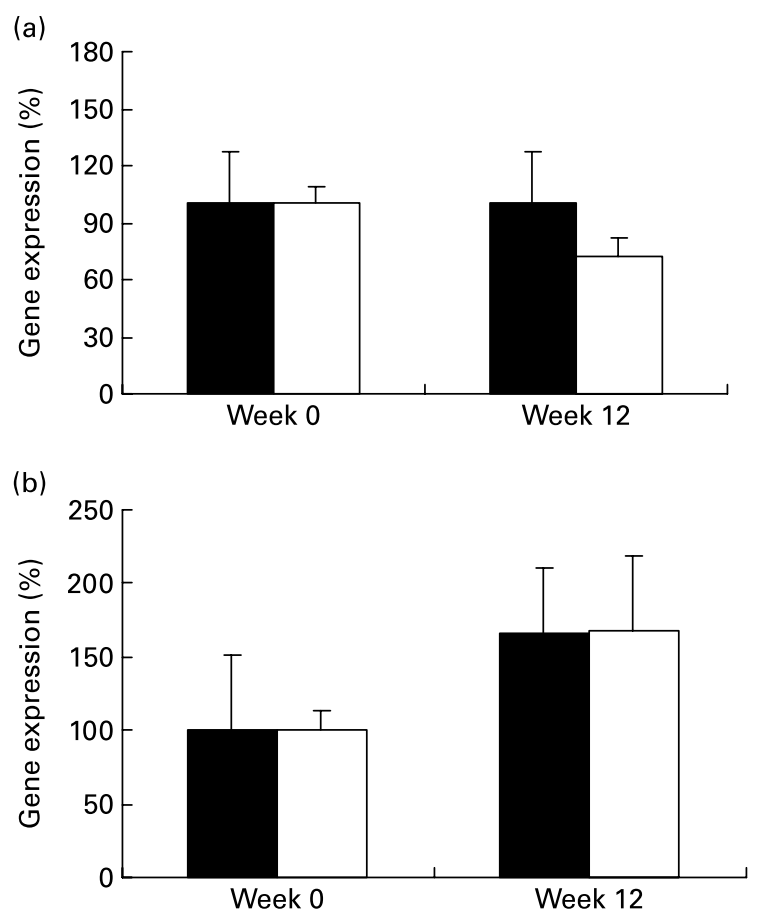

Fig. 3. Relative expression of (a) PPAR $\alpha$ and (b) lipoprotein lipase (LPL) mRNA in the liver of 12 weeks' green tea-supplemented $(\square ; n 6)$ and control $(\square ; n$ 4) obese dogs. Values are presented as means with their standard errors. For details of animals and procedures, see Materials and methods.
Clinical studies have shown that body weight and fat mass of human subjects and animals given green tea catechins decreased significantly ${ }^{(28,48)}$. In the present study, body weight and body composition were not affected by green tea supplementation. During treatment, our dogs were fed approximately according to the National Research Council recommendation for maintenance, which could explain why body weight remains stable in the green tea and control groups. An elevation of the expression of PPAR $\gamma$, LPL and GLUT4 in adipose tissue, without any effect on plasma NEFA concentration, would enhance fat depots - similar to thiazolidinedione ${ }^{(49)}$. An increase in uncoupling protein activity in adipose tissue might regulate the energy balance by uncoupling mitochondrial respiration - as has been shown with thiazolidinedione ${ }^{(50)}$. Some reports suggested that green tea catechins not only promote energy expenditure but also stimulate the oxidation of lipids by the known inhibitory effect of catechins and notably EGCG on catechol- $O$ methyltransferase, an enzyme that degrades noradrenaline ${ }^{(51)}$. Taken together, we can hypothesize that green tea catechins enhance lipid catabolism, which could counteract the PPAR $\gamma$ agonist-induced lipogenesis. This could explain the absence of change in body composition after green tea treatment. Green tea catechins could trigger a shift of fat distribution from visceral to subcutaneous adipose depots as has been shown with a PPAR $\gamma$ agonist, the pioglitazone ${ }^{(52)}$. It is well known that visceral adipocytes are lipolytically more active than subcutaneous fat cells and removal of visceral fat enhances insulin sensitivity ${ }^{(34)}$.

In conclusion, the present results demonstrate that extended nutritional supplementation with green tea may reverse obesity-related metabolic disturbances by improving insulin sensitivity and decreasing VLDL-TAG concentrations. We also 
(a)

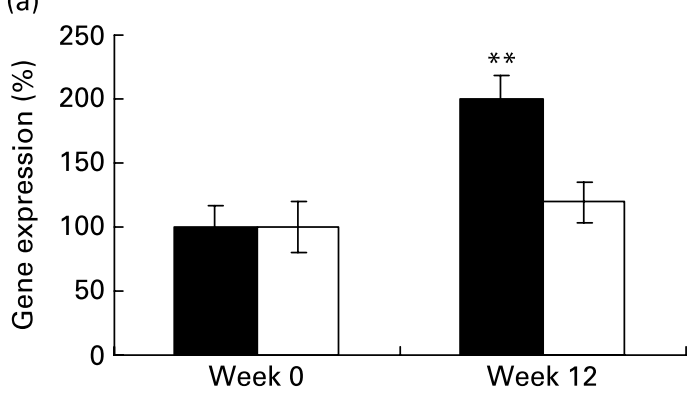

(b)

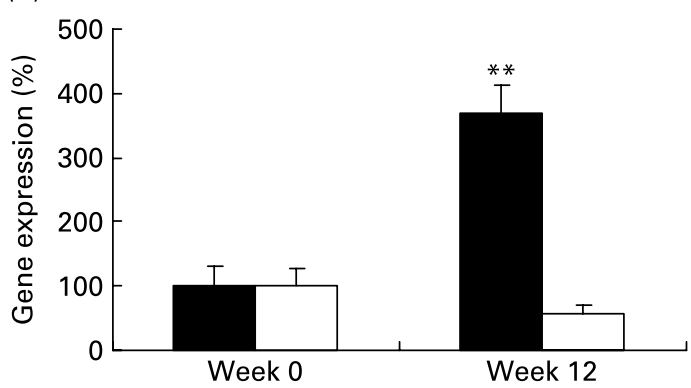

(c)

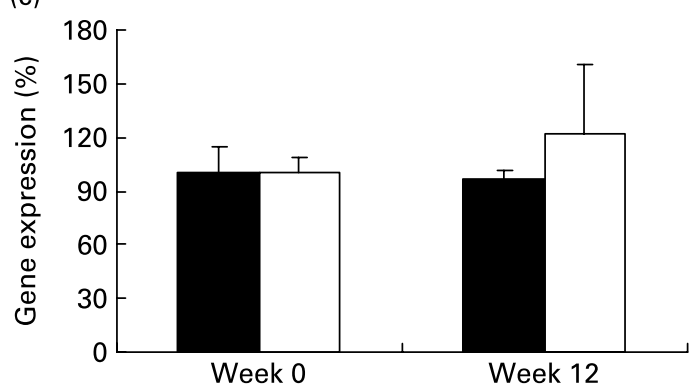

Fig. 4. Relative expression of (a) $P P A R \alpha$, (b) lipoprotein lipase (LPL) and (c) GLUT4 mRNA in skeletal muscle of 12 weeks' green tea-supplemented $(\boldsymbol{\square} ; n$ 6) and control $(\square ; n 4)$ obese dogs. Values are presented as means with their standard errors. ${ }^{* *} P<0.01 \mathrm{v}$. baseline (week 0 ). For details of animals and procedures, see Materials and methods.

observed an increase in the expression of PPAR $\alpha$ and PPAR $\gamma$, important transcription factors involved in lipid and glucose homeostasis. The mRNA expression of their target genes (LPL, adiponectin and GLUT4) was increased and could explain the beneficial effects of green tea in obese, insulinresistant dogs. According to previous studies ${ }^{(19,20)}$, these results suggest that green tea (or its catechins) may be new natural PPAR activators. The obese, insulin-resistant dog model can thus be used, in further studies, to assess the in vivo effects of EGCG, which is the principal - and probably the most active - catechin in green tea.

\section{Acknowledgements}

The authors are grateful to Samuel Ninet, Gérald Pondevie and Philippe Bleis for taking care of the animals and for technical assistance. None of the authors has financial or personal conflicts of interest with regard to this study.

\section{References}

1. Zimmet P, Alberti KG \& Shaw J (2001) Global and societal implications of the diabetes epidemic. Nature 414, 782-787.

2. Alberti KG \& Zimmet PZ (1998) Definition, diagnosis and classification of diabetes mellitus and its complications. Part 1: diagnosis and classification of diabetes mellitus provisional report of a WHO consultation. Diabet Med 15, 539-553.

3. Zavaroni I, Bonini L, Fantuzzi M, Dall'Aglio E, Passeri M \& Reaven GM (1994) Hyperinsulinaemia, obesity, and syndrome X. J Intern Med 235, 51-56.

4. Cheng TO (2006) All teas are not created equal: the Chinese green tea and cardiovascular health. Int $J$ Cardiol 108, 301-308.

5. Graham HN (1992) Green tea composition, consumption, and polyphenol chemistry. Prev Med 21, 334-350.

6. Okuda T, Mori K \& Hayatsu H (1984) Inhibitory effect of tannins on direct-acting mutagens. Chem Pharm Bull (Tokyo) 32, $3755-3758$

7. Yang CS \& Wang ZY (1993) Tea and cancer. J Natl Cancer Inst 85, 1038-1049.

8. Sung H, Nah J, Chun S, Park H, Yang SE \& Min WK (2000) In vivo antioxidant effect of green tea. Eur J Clin Nutr 54, 527-529.

9. Cao Y \& Cao R (1999) Angiogenesis inhibited by drinking tea. Nature 398, 381.

10. Anderson RA \& Polansky MM (2002) Tea enhances insulin activity. J Agric Food Chem 50, 7182-7186.

11. Tsuneki H, Ishizuka M, Terasawa M, Wu JB, Sasaoka T \& Kimura I (2004) Effect of green tea on blood glucose levels and serum proteomic patterns in diabetic $(\mathrm{db} / \mathrm{db})$ mice and on glucose metabolism in healthy humans. BMC Pharmacol 4, 18.

12. Wu LY, Juan CC, Ho LT, Hsu YP \& Hwang LS (2004) Effect of green tea supplementation on insulin sensitivity in SpragueDawley rats. J Agric Food Chem 52, 643-648.

13. Sayama K, Lin S, Zheng G \& Oguni I (2000) Effects of green tea on growth, food utilization and lipid metabolism in mice. In Vivo 14, 481-484.

14. Kao YH, Hiipakka RA \& Liao S (2000) Modulation of endocrine systems and food intake by green tea epigallocatechin gallate. Endocrinology 141, 980-987.

15. Waltner-Law ME, Wang XL, Law BK, Hall RK, Nawano M \& Granner DK (2002) Epigallocatechin gallate, a constituent of green tea, represses hepatic glucose production. J Biol Chem 277, 34933-34940.

16. Ashida H, Furuyashiki T, Nagayasu H, Bessho H, Sakakibara H, Hashimoto T \& Kanazawa K (2004) Anti-obesity actions of green tea: possible involvements in modulation of the glucose uptake system and suppression of the adipogenesis-related transcription factors. Biofactors 22, 135-140.

17. Wu LY, Juan CC, Hwang LS, Hsu YP, Ho PH \& Ho LT (2004) Green tea supplementation ameliorates insulin resistance and increases glucose transporter IV content in a fructose-fed rat model. Eur J Nutr 43, 116-124.

18. Jiao HL, Ye P \& Zhao BL (2003) Protective effects of green tea polyphenols on human HepG2 cells against oxidative damage of fenofibrate. Free Radic Biol Med 35, 1121-1128.

19. Lee K (2004) Transactivation of peroxisome proliferator-activated receptor alpha by green tea extracts. $J$ Vet Sci 5, 325-330.

20. Li RW, Douglas TD, Maiyoh GK, Adeli K \& Theriault AG (2006) Green tea leaf extract improves lipid and glucose homeostasis in a fructose-fed insulin-resistant hamster model. J Ethnopharmacol 104, 24-31.

21. Bailhache E, Ouguerram K, Gayet C, Krempf M, Siliart B, Magot T \& Nguyen P (2003) An insulin-resistant hypertriglyceridaemic normotensive obese dog model: assessment of insulin resistance by the euglycaemic hyperinsulinaemic clamp in 
combination with the stable isotope technique. J Anim Physiol Anim Nutr (Berl) 87, 86-95.

22. Bailhache E, Nguyen $P$, Krempf M, Siliart B, Magot $T$ \& Ouguerram K (2003) Lipoproteins abnormalities in obese insulin-resistant dogs. Metabolism 52, 559-564.

23. Kirkness EF, Bafna V, Halpern AL, et al. (2003) The dog genome: survey sequencing and comparative analysis. Science 301, 1898-1903.

24. Desvergne B \& Wahli W (1999) Peroxisome proliferator-activated receptors: nuclear control of metabolism. Endocr Rev 20, 649-688.

25. Laflamme DP (2005) Nutrition for aging cats and dogs and the importance of body condition. Vet Clin North Am Small Anim Pract 35, 713-742.

26. Beard JC, Bergman RN, Ward WK \& Porte D Jr (1986) The insulin sensitivity index in nondiabetic man. Correlation between clamp-derived and IVGTT-derived values. Diabetes 35, 362-369.

27. Livak KJ \& Schmittgen TD (2001) Analysis of relative gene expression data using real-time quantitative PCR and the 2(-Delta Delta C(T)) method. Methods 25, 402-408.

28. Klaus S, Pultz S, Thone-Reineke C \& Wolfram S (2005) Epigallocatechin gallate attenuates diet-induced obesity in mice by decreasing energy absorption and increasing fat oxidation. Int J Obes (Lond) 29, 615-623.

29. Bu-Abbas A, Dobrota M, Copeland E, Clifford MN, Walker R \& Ioannides C (1999) Proliferation of hepatic peroxisomes in rats following the intake of green or black tea. Toxicol Lett 109, 69-76.

30. Swezey RR, Aldridge DE, LeValley SE, Crowell JA, Hara Y \& Green CE (2003) Absorption, tissue distribution and elimination of 4-[(3)h]-epigallocatechin gallate in beagle dogs. Int J Toxicol 22, 187-193.

31. Ryu OH, Lee J, Lee KW, Kim HY, Seo JA, Kim SG, Kim NH, Baik SH, Choi DS \& Choi KM (2006) Effects of green tea consumption on inflammation, insulin resistance and pulse wave velocity in type 2 diabetes patients. Diabetes Res Clin Pract 71, 356-358.

32. Radziuk J (2000) Insulin sensitivity and its measurement: structural commonalities among the methods. J Clin Endocrinol Metab 85, 4426-4433.

33. Park SY, Choi GH, Choi HI, Ryu J, Jung CY \& Lee W (2005) Calorie restriction improves whole-body glucose disposal and insulin resistance in association with the increased adipocytespecific GLUT4 expression in Otsuka Long-Evans Tokushima fatty rats. Arch Biochem Biophys 436, 276-284.

34. Abel ED, Peroni O, Kim JK, Kim YB, Boss O, Hadro E, Minnemann T, Shulman GI \& Kahn BB (2001) Adipose-selective targeting of the GLUT4 gene impairs insulin action in muscle and liver. Nature 409, 729-733.

35. Mlinar B, Marc J, Janez A \& Pfeifer M (2007) Molecular mechanisms of insulin resistance and associated diseases. Clin Chim Acta 375, 20-35.

36. Kobayashi Y, Suzuki M, Satsu H, Arai S, Hara Y, Suzuki K, Miyamoto Y \& Shimizu M (2000) Green tea polyphenols inhibit the sodium-dependent glucose transporter of intestinal epithelial cells by a competitive mechanism. J Agric Food Chem 48, $5618-5623$.

37. Kono S, Shinchi K, Wakabayashi K, Honjo S, Todoroki I, Sakurai Y, Imanishi K, Nishikawa H, Ogawa S \& Katsurada
M (1996) Relation of green tea consumption to serum lipids and lipoproteins in Japanese men. J Epidemiol 6, 128-133.

38. Tokunaga S, White IR, Frost C, Tanaka K, Kono S, Tokudome S, Akamatsu T, Moriyama T \& Zakouji H (2002) Green tea consumption and serum lipids and lipoproteins in a population of healthy workers in Japan. Ann Epidemiol 12, 157-165.

39. Schoonjans K, Peinado-Onsurbe J, Lefebvre AM, Heyman RA, Briggs M, Deeb S, Staels B \& Auwerx J (1996) PPARalpha and PPARgamma activators direct a distinct tissue-specific transcriptional response via a PPRE in the lipoprotein lipase gene. EMBO J 15, 5336-5348.

40. Yee WL, Wang Q, Agdinaoay T, Dang K, Chang H, Grandinetti A, Franke AA \& Theriault A (2002) Green tea catechins decrease apolipoprotein B-100 secretion from HepG2 cells. Mol Cell Biochem 229, 85-92.

41. Allister EM, Borradaile NM, Edwards JY \& Huff MW (2005) Inhibition of microsomal triglyceride transfer protein expression and apolipoprotein B100 secretion by the citrus flavonoid naringenin and by insulin involves activation of the mitogen-activated protein kinase pathway in hepatocytes. Diabetes 54, $1676-1683$.

42. Li L, Stillemark-Billton P, Beck C, et al. (2006) Epigallocatechin gallate increases the formation of cytosolic lipid droplets and decreases the secretion of apoB-100 VLDL. J Lipid Res 47, 67-77.

43. Gebel T, Arand M \& Oesch F (1992) Induction of the peroxisome proliferator activated receptor by fenofibrate in rat liver. FEBS Lett 309, 37-40.

44. Sterchele PF, Sun H, Peterson RE \& Vanden Heuvel JP (1996) Regulation of peroxisome proliferator-activated receptor-alpha mRNA in rat liver. Arch Biochem Biophys 326, 281-289.

45. Davies GF, McFie PJ, Khandelwal RL \& Roesler WJ (2002) Unique ability of troglitazone to up-regulate peroxisome proliferator-activated receptor-gamma expression in hepatocytes. J Pharmacol Exp Ther 300, 72-77.

46. Sen CK \& Packer L (1996) Antioxidant and redox regulation of gene transcription. FASEB J 10, 709-720.

47. Wang P, Anderson PO, Chen S, Paulsson KM, Sjogren HO \& Li $S$ (2001) Inhibition of the transcription factors AP-1 and NFkappaB in $\mathrm{CD} 4 \mathrm{~T}$ cells by peroxisome proliferator-activated receptor gamma ligands. Int Immunopharmacol 1, 803-812.

48. Nagao T, Komine $\mathrm{Y}$, Soga S, Meguro S, Hase T, Tanaka Y \& Tokimitsu I (2005) Ingestion of a tea rich in catechins leads to a reduction in body fat and malondialdehyde-modified LDL in men. Am J Clin Nutr 81, 122-129.

49. Fonseca V (2003) Effect of thiazolidinediones on body weight in patients with diabetes mellitus. Am J Med 115, Suppl. 8A, $42 \mathrm{~S}-48 \mathrm{~S}$

50. Cortright RN, Zheng D, Jones JP, Fluckey JD, DiCarlo SE, Grujic D, Lowell BB \& Dohm GL (1999) Regulation of skeletal muscle UCP-2 and UCP-3 gene expression by exercise and denervation. Am J Physiol 276, E217-E221.

51. Dulloo AG, Seydoux J, Girardier L, Chantre P \& Vandermander $J$ (2000) Green tea and thermogenesis: interactions between catechin-polyphenols, caffeine and sympathetic activity. Int $J$ Obes Relat Metab Disord 24, 252-258.

52. Miyazaki Y, Mahankali A, Matsuda M, Mahankali S, Hardies J, Cusi K, Mandarino LJ \& Defronzo RA (2002) Effect of pioglitazone on abdominal fat distribution and insulin sensitivity in type 2 diabetic patients. J Clin Endocrinol Metab 87, 2784-2791. 